\title{
PENGARUH PENGETAHUAN AKUNTANSI, KOMITMEN ORGANISASI, KARAKTERISTIK WIRAUSAHA DAN KETIDAKPASTIAN LINGKUNGAN TERHADAP KINERJA MANAJERIAL PADA “COFFEE SHOP” DI BANDAR LAMPUNG
}

\author{
Febby Fadlika Syabila1, Reni Oktavia2, Chara P. T. Tubarat3 \\ ${ }^{1}$ Fakultas Ekonomi dan Bisnis, Universitas Lampung \\ ${ }^{2}$ Fakultas Ekonomi dan Bisnis, Universitas Lampung \\ 3 Fakultas Ekonomi dan Bisnis, Universitas Lampung
}

\section{Informasi Naskah}

Update Naskah:

Dikumpulkan: 20 Agustus 2020

Diterima: 3 Januari 2021

Terbit/Dicetak: 24 Januari 2021

\section{Keywords:}

Accounting, commitment of organization, characteristic of entrepreneurs and uncertainty environment, managerial

performance.

\section{Abstract}

Currently, coffee shops or commonly known as coffee shops are not foreign to the ears. For in Bandar Lampung itself there are lots of coffee shops ranging from lower class to upper class. Various types of consumers make business competition something that must be considered for entrepreneurs in running and maintaining their business. The purpose of this study is to determine the effect of accounting knowledge, organizational commitment, environmental uncertainty and entrepreneurial characteristics on managerial performance at a coffee shop in Bandar Lampung. The research method used is causal associative research, namely research that aims to analyze the relationship between a variable with other variables. The sampling technique used in this study is a sampling technique with purposive sampling method. Methods of data collection using observation and questionnaires. The result of this research is that there is a positive influence between accounting knowledge, organizational commitment and entrepreneurial characteristics on managerial performance. 


\section{A. PENDAHULUAN}

Kopi merupakan salah satu hasil komoditi perkebunan yang bernilai ekonomis cukup tinggi di antara tanaman perkebunan lainnya, serta berperan penting sebagai sumber devisa negara(Rahardjo, 2012). Dalam acara Festival Kopi Lampung 2019 Gubernur Lampung menyatakan bahwa Lampung adalah salah satu provinsi penghasil kopi terbesar di Indonesia. Indonesia sekarang menempati posisi keempat sebagai pemasok kopi dunia.

Berdasarkan fakta tersebut muncullah banyak coffee shop. Saat ini coffee shop atau yang biasa dikenal dengan kedai kopi sudah tidak asing lagi di telinga. Untuk di Bandar Lampung sendiri terdapat banyak sekali coffee shop mulai dari kelas bawah sampai dengan kelas atas. Sekarang masyarakat Indonesia khususnya di Lampung lebih memilih coffee shop untuk menikmati kopi daripada di rumah. Menikmati kopi di kedai kopi langsung telah menjadi gaya hidup masyarakat Indonesia masa kini. Coffee shop merupakan suatu tempat yang menyediakan minuman seperti kopi, teh, dan minuman lainnya. Terdapat juga beberapa coffee shop yang menjual makanan ringan sebagai pelengkap.

Coffee shop telah banyak memiliki manfaat tersendiri bagi berbagai tipe konsumen. Konsumen memanfaatkan coffee shop untuk kepentingan mereka masing-masing. Contohnya ialah sebagai tempat untuk bersantai atau mengahbiskan waktu bersama teman dekat. Ada juga yang menggunakan coffee shop sebagai meeting point. Hal tersebutlah yang menjadi alasan mengapa coffee shop tidak pernah sepi pengunjung hingga saat ini.

Berbagai jenis konsumen membuat persaingan usaha menjadi sesuatu hal yang harus diperhatikan untuk para wirausaha dalam menjalankan dan mempertahankan usahanya. Segala usaha memiliki persaingan masing-masing, sehingga di butuhkan kinerja manajerial yang baik agar dapat terus unggul dalam banyaknya persaingan. KPKL (Komunitas Pecinta Kopi Lampung) menyatakan pada tahun 2018 sampai saat ini sudah banyak coffee shop yang mengalami kebangkrutan yaitu sebanyak 14 coffee shop. Kebangkrutan ini disebabkan beberapa hal di antaranya tidak ada perencanaan tujuan bisnis yang matang, marketing yang buruk, tim yang tidak solid, pencatatan keuangan yang buruk.

Kinerja manajerial merupakan kinerja para individu dalam kegiatan-kegiatan manajerial, seperti: perencanaan, investigasi, koordinasi, evaluasi, pengawasan, pengaturan staf, negosiasi dan perwakilan. Kasmir (2016) menguraikan faktor-faktor yang memengaruhi kinerja manajerial yang salah satunya diambil dalam penelitian ini yaitu Pengetahuan, kepribadian atau karakteristik, dan juga komitmen. Principles Board (APB) dalam Suwardjono (2002)menjelaskan Akuntansi adalah seni pencatatan, penggolongan, dan peringkasan transaksi dan kejadian bersifat keuangan dengan cara yang berdaya guna dan dalam bentuk satuan uang, dan penginterpretasian hasil proses tersebut.

Karakteristik wirausaha merupakan keseluruhan cara seorang untuk berinteraksi dan melihat peluang usaha serta menerjemahkannya menjadi usaha nyata yang memiliki nilai tambah serta memiliki karakteristik tingkat pengendalian internal, tingkat energi tinggi, kebutuhan tinggi akan berprestasi, tidak bekerja lebih giat karena adanya imbalan, toleransi terhadap ambiguitas, kepercayaan diri, dan berorientasi pada aksi.

Sebuah penelitian mengenai pengaruh pengetahuan akuntansi dan kepribadian wirausaha terhadap kinerja manajerial dilakukan oleh Sirega (2009). Penelitian Siregar (2009) mengenai pengaruh pengetahuan akuntansi dan kepribadian wirausaha terhadap kinerja manajerial dilakukan pada perusahaan jasa yang terdaftar di kota Medan. Siregar dan Erlina menemukan bahwa pengetahuan akuntansi berpengaruh negatif dan signifikan terhadap kinerja manajerial, dan kepribadian wirausaha mempunyai pengaruh positif namun tidak signifikan terhadap kinerja manajerial.

Mathieu dan Zajac (1990) dalam Ida dan Maria (2017) menyatakan bahwa komitmen organisasi adalah terikatnya perseorangan terhadap organisasi. Komitmen organisasi merupakan salah satu ukuran yang digunakan di dalam memahami hubungan antara tujuan dan kinerja. Komitmen organisasi sangat dekat hubungannya dengan tingkah laku seseorang atau individu yang berkaitan dengan organisasi 
tempat individu tersebut bekerja.

Terdapat beberapa penelitian terdahulu salah satunya menurut Ridwan dan Sandi, (2019)komitmen organisasi berpengaruh positif terhadap kinerja manajerial, tidak dengan penelitian Wijayanti (2012)menyatakan bahwa komitmen organisasi berpengaruh negatif terhadap kinerja manajerial. Ketidakpastian merupakan faktor dari suatu situasi yang dihadapi oleh sebagian manajer pada sebuah organisasi yang sulit untuk diprediksi. Dampak yang ditimbulkan dari ketidakpastian ini adalah hasil dari keputusan yang telah dibuat mungkin hasilnya akan berbeda dari yang telah diperkirakan saat mengambil keputusan. Menurut Subkhi dan Jauhan (2013)ketidakpastian lingkungan merupakan suatu keadaan yang dalam hal ini organisasi atau manajer tidak mempunyai informasi yang cuku mengenai keadaan lingkungannya, sehingga akan menyebkan timbulnya kesulitan dalam memperkirakan perubahan-perubahan lingkungan yang akan terjadi. Kondisi ketidakpastian lingkungan dan persaingan usaha yang sangat ketat dapat menjadikan informasi sebagai komoditas yang sangat berguna bagi suatu perusahaan dalam kegiatan perencanaan, pengendalian serta pembuatan suatu keputusan.

Beberapa penelitian yang terkait dengan ketidakpastian lingkungan, salah satunya dari Desmiyawati(2010)telah melakukan penelitian di seluruh perusahaan perbankan di Pekanbaru. Hasil penelitian menghasilkan ketidakpastian lingkungan tidak berpengaruh terhadap kinerja manajerial, sedangkan hasil penelitian yang dilakukan olehHerawati dkk (2015), dan Fiolita dkk (2015) menunjukkan bahwa ketidakpastian lingkungan berpengaruh signifikan positif terhadap kinerja manajerial. Berdasarkan latar belakang tersebut, peneliti melakukan penelitian dnegan tujuan untuk mengetahui pengaruh pengetahuan akuntansi, komitmen organisasi, ketidakpastian lingkungan dan karakteristik wirausaha terhadap kinerja manajerial pada coffee shop yang ada di Bandar Lampung.

\section{B. LANDASAN TEORI DAN PENGEMBANGAN HIPOTESIS}

\section{Teori Atribusi}

Menurut Fritz Heider sebagai pencetus teori atribusi, teori atribusi merupakan teori yang menjelaskan tentang perilaku seseorang. Teori atribusi menjelaskan mengenai proses bagaimana menentukan penyebab dan motif tentang perilaku seseorang. Fritz Heider juga menyatakan bahwa kekuatan internal (atribut personal seperti kemampuan, usaha dan kelelahan) dan kekuatan eksternal (atribut lingkungan seperti aturan dan cuaca) itu bersama-sama menentukan perilaku manusia. Dia menekankan bahwa merasakan secara tidak langsung adalah determinan paling penting untuk perilaku. Atribusi internal maupun eksternal telah dinyatakan dapat memengaruhi terhadap evaluasi kinerja individu, misalnya dalam menentukan bagaimana cara atasan memperlakukan bawahannya, dan memengaruhi sikap dan kepuasaan individu terhadap kerja. Orang akan berbeda perilakunya jika mereka lebih merasakan atribut internalnya daripada atribut eksternalnya.

Dalam penelitian ini, peneliti mengambil teori atribusi karena peneliti melakukan studi empiris untuk mengetahui faktor-faktor apakah karyawan dan manajer dapat memengaruhi kinerja manajerial dalam perusahaan.

\section{Pengertian Akuntansi}

Secara etimologis, menurut Hoetomo (2005)bahwa defenisi pengetahuan adalah ilmu. Seperangkat ilmu yang tersusun secara sistematis mengatur satu atau lebih teori pokok dan sejumlah prinsip umum yang biasanya ditunjukkan secara kuantitatif yang menunjukkan prediksi dan dalam kondisi-kondisi tertentu dapat mengontrol keadaan di masa depan. Indikator pengetahuan akuntansi menggunakan dua dimensi pengukuran yang biasanya digunakan dalam kajian audit Bonner (1994) yaitu: pengetahuan deklaratif dan pengetahuan prosedural. 


\section{Definisi Komitmen Organisasi}

Sutrisno (2014), menyatakan bahwa Komitmen organisasi merupakan kemauan usaha yang tinggi untuk organisasi dan suatu keyakinan tertentu dalam penerimaan terhadap nila-nilai organisasi, sedangkan Menurut Allen dan Meyer dalam Kurniawan (2015)komitmen organisasi adalah suatu konstruk psikologis yang merupakan karakteristik hubungan anggota organisasi dengan organisasinya, dan memiliki implikasi terhadap keputusan individu untuk melanjutkan keanggotaannya dalam berorganisasi. Meyer, Natalie, dan Catherine (1993) mengemukakan tiga dimensi mengenai komitmen organisasi yaitu komitmen afektif, komitmen berkelanjutan serta komitmen normatif.

\section{Karakteristik Wirausaha}

Definisi karakteristik menurut Allport dalam Rahman (2013)adalah keseluruhan total cara seorang individu bereaksi dan berinteraksi dengan yang lain. Hal tersebut sering digambarkan dari segi ciri-ciri yang dapat diukur dan diperlihatkan seseorang. Secara etimologis, wirausaha merupakan terjemahan dari kata entreprenuer yang berasal dari bahasa Perancis entreprendre. Wirausaha adalah Orang yang menciptakan kerja bagi orang lain dengan cara mendirikan, mengembangkan, dan melembagakan perusahaan miliknya sendiri serta bersedia mengambil risiko pribadi untuk menemukan peluang berusaha dan secara kreatif menggunakan potensi-potensi dirinya untuk mengenali produk, mengelola, dan menentukan cara produksinya, menyusun operasi untuk pengadaan produk, memasarkan produknya, serta mengatur permodalan operasinya.

Berdasarkan pendapat-pendapat tersebut, kepribadian wirausaha dapat diartikan sebagai keseluruhan cara seorang untuk berinteraksi memberikan tanggapan yang positif terhadap peluang berusaha dan secara kreatif menggunakan potensi-potensi dirinya untuk mengenali produk, mengelola, dan menentukan cara produksi, menyusun operasi untuk pengadaan produk, memasarkan produk, serta mengatur permodalan operasi perusahaannya untuk memperoleh keuntungan bagi diri sendiri dan atau pelayanan yang lebih baik pada pelanggan dan masyarakat.

\section{Ketidakpastian Lingkungan}

Ketidakpastian merupakan faktor dari suatu situasi yang dihadapi oleh sebagian manajer pada sebuah organisasi yang sulit untuk diprediksi. Setiap organisasi memiliki persepsi yang berbeda terhadap kondisi lingkungan yang akan dihadapinya. MenurutSubkhi dan Jauhan (2013) adalah suatu keadaan yang dalam hal ini organisasi atau manajer tidak mempunyai informasi yang cukup tentang keadaan lingkungannya, sehingga akan menyebabkan timbulnya kesulitan dalam memperkirakan perubahaperubahan yang akan terjadi di lingkungannya. Dari beberapa pendapat mengenai ketidakpastian lingkungan yang telah dipaparkan di atas dapat isimpulan bahwa ketidakpastian lingkungan merupakan ketidakmampuan seorang manajer atau pimpinan memprediksi keadaan dimasa yang akan datang dengan tepat dan akurat dari seluruh faktor yang secara langsung atau tidak langsung dapat memengaruhi seorang manajer atau pemimpin dalam mengambil keputusan.

\section{Kinerja Manajerial}

Menurut Suyadi dalamMangkunegara (2017), Kinerja adalah hasil kerja yang dapat dicapai oleh seseorang atau sekelompok orang dalam satu organisasi, sesuai dengan wewenang dan tanggungjawab masing-masing, dalam rangka upaya mencapai tujuan organisasi bersangkutan secara legal, tidak melanggar hukum dan sesuai dengan moral dan etika. Selanjutnya menurut Masram dan Mu'a(2017)kinerja merupakan hasil-hasil fungsi pekerjaan atau kegiatan seseorang maupun kelompok dalam suatu organisasi yang dipengaruhi oleh berbagai faktor untuk mencapai tujuan organisasi dalam periode waktu tertentu. Kinerja perusahaan adalah tingkat pencapaian hasil dalam rangka mewujudkan tujuan perusahaan. 


\section{Hipotesis Penelitian}

Adapun hipotesis dalam peneltiian ini ialah:

1. Pengaruh Pengetahuan Akuntansi Terhadap Kinerja Manajerial

Pengujian terhadap pengaruh pengetahuan akuntansi terhadap kinerja manajerial pernah dilakukan oleh Siregar (2013)yang meneliti tentang pengaruh pengetahuan akuntansi terhadap kinerja manajerial pada usaha kecil menengah di Kabupaten Sleman Yogyakarta. Hasil penelitian tersebut menyatakan pengetahuan akuntansi berpengaruh positif terhadap kinerja manajerial pada usaha kecil menengah. Sebelumnya juga telah meneliti tentang pengaruh pengetahuan akuntansi terhadap kinerja manajerial pada perusahaan jasa di kota Medan. Hasil tersebut menunjukkan pengetahuan akuntansi berpengaruh positif terhadap kinerja manajerial pada perusahaan jasa di kota Medan. Pendapat tersebut berbeda dengan Mardiana dkk (2020)yang meneliti tentang pengaruh pengetahuan akuntansi terhadap kinerja manajerial pada perusahaan jasa di kota Padang. Hasil penelitian tersebut menunjukkan pengetahuan akuntansi tidak berpengaruh terhadap kinerja manajerial pada perusahaan jasa di kota Padang. Berdasarkan dari berbagai penelitian di atas peneliti mengambil hipotesis sebagai berikut:

H1: Pengetahuan Akuntansi berpengaruh positif terhadap kinerja manajerial pada coffee shop di Bandar Lampung.

2. Pengaruh Komitmen Organisasi Terhadap Kinerja Manajerial

Beberapa organisasi menyertakan unsur komitmen di dalam suatu lowongan pekerjaan, yang yang dalam hal ini komitmen ini merupakan slah satu prasyarat untuk menduduki pangkat atau posisi tertentu. Komitmen organisasi salah satu konsep tingkah laku pada pekerjaan yang berhubungan dengan ada tidaknya keterkaitan perseorangan pada organisasi. Angel dan Perry (1981) dalam Sengkeh dkk (2017) menyatakan bahwa individu yang memiliki komitmen organisasi yang kuat, akan menimbulkan perseorangan berupaya semaksimal mungkin untuk meraih tujuan organisasi sesuai dengan tujuan dan keperluan organisasinya. Sengkeh dkk (2017)melakukan penelitian dan menunjukkan bahwa komitmen organisasi berpengaruh positif dan signifikan pada kinerja manajerial. Berbeda dengan penelitian yang dilakukan Ridwan dan Hamelinda, (2017)menyatakan bahwa komitmen organisasi berpengaruh negatif terhadap kinerja manajerial. mengatakan bahwa tingginya kinerja yang dihasilkan oleh seorang manajer berasal dari tingginya sebuah komitmen dari perseorangan kepada tugas yang diberikan. Berdasarkan dari berbagai penelitian di atas peneliti mengambil hipotesis sebagai berikut:

H2: Komitmen organisasi berpengaruh negatif terhadap kinerja manajerial pada coffee shop di Bandar Lampung.

3. Pengaruh Ketidakpastian Lingkungan Terhadap Kinerja Manajerial

Chenhall dan Morris (1986) dalam Fiolita et al. (2015) menyatakan bahwa ketidakpastian lingkungan merupakan faktor kontijensi yang penting sebab ketidakpastian lingkungan dapat menyebabkan proses perencanaan dan control menjadi lebih sulit. Perencanaan menjadi bermasalah dalam kondisi yang tidak pasti karena tidak terprediksinya lingkungan akan semakin menurunkan kinerja manajerial. Organisasi yang sukses adalah organisasi yang dapat menyesuaikan diri dengan perubahan-perubahan yang terjadi dalam lingkungannya dan secara proaktif mampu merubahnya. Hasil penelitian Rahmawati dan Nuraini (2012)menghasilkan bahwa ketidakpastian lingkungan tidak berpengaruh terhadap kinerja manajerial.

H3: Ketidakpastian lingkungan berpengaruh negatif terhadap kinerja manajerial pada coffee shop di Bandar Lampung.

4. Pengaruh Karakteristik Wirausaha Terhadap Kinerja Manajerial

Menurut Stoner dan Edwart dalam Winardi (2003)menjelaskan bahwa seorang manajer dapat disebut seorang wirausaha, apabila ia sanggup melaksanakan perubahan-perubahan yang bersifat inovatif 
dalam proses produksi yang di manajer olehnya. Seorang wirausaha pada situasi dan kondisi tertentu (apabila perusahaan kecil yang dibentuknya telah berkembang menjadi perusahaan besar) harus pula melaksanakan tugas-tugas seorang manajer dalam wujud melaksanakan fungsi-fungsi manajerial seperti perencanaan, pengorganisasian, memimpin dan mengawasi. Peneliti Siregar (2009) meneliti tentang pengaruh kepribadian wirausaha terhadap kinerja manajerial pada perusahaan jasa di kota medan. Hasil penelitian menunjukkan bahwa kepribadian wirausaha tidak berpengaruh terhadap kinerja manajerial dalam suatu perusahaan. Sama denganPutra (2018) menyatakan bahwa kepribadian kewirausahaan berpengaruh signifikan terhadap kinerja manajerial. Berdasarkan dari berbagai penelitian di atas peneliti mengambil hipotesis sebagai berikut:

H4: Karakteristik Wirausaha Berpengaruh Positif Terhadap Kinerja Manajerial pada coffee shop di Bandar Lampung.

\section{METODE PENELITIAN}

\section{Jenis Penelitian dan Sampel Penelitian}

Penelitian yang dilakukan oleh peneliti adalah penelitian asosiatif kausal yaitu penelitian yang bertujuan untuk menganalisis hubungan antara suatu variabel dengan variabel yang lainnya. Penelitian ini menggunakan teknik pengambilan sampel purposif sampling dengan kriteria coffee shop yang buka tujuh hari dalam seminggu, coffee shop harus memiliki minimal satu manajer aktif, coffee Shop yang telah beroperasi selama 12 bulan, coffee shop yang memiliki jam operasi minimal 12 jam per hari. Terpilih 28 sampel yang merupakan coffee shop yang berada di sekitar Bandar Lampung.

\section{Teknik Pengumpulan Data dan Teknik Analisis}

Teknik pengumpulan data melalui observasi dan kuesioner. Teknik analisis data yang digunakan adalah uji asumsi klasik yang terdiri dari asumsi normalitas, multikolinearitas dan heteroskedisitas, sedangkan uji hipotesis menggunakan model regresi berganda. Berikut merupakan rumus yang digunakan untuk uji hipotesis:

$$
\mathbf{Y}=\mathbf{a}+\mathbf{b}_{1} \mathbf{X}_{1}+\mathbf{b}_{2} \mathbf{X}_{2}+\mathbf{b}_{3} \mathbf{X}_{3}+\mathbf{b}_{4} \mathbf{X}_{4}
$$

Keterangan:

$\begin{array}{ll}\mathrm{a} & =\text { Konstanta } \\ \mathrm{b} 1, \mathrm{~b} 2 \mathrm{~b} 3 & =\text { Koefisien Regresi } \\ \mathrm{Y} & =\text { Kinerja Manajerial } \\ \mathrm{X} 1 & =\text { Pengetahuan Akuntansi } \\ \mathrm{X} 2 & =\text { Komitmen Organisasi } \\ \mathrm{X} 3 & =\text { Karakteristik Wirausaha } \\ \mathrm{X} 4 & =\text { Ketidakpastian Lingkungan }\end{array}$

\section{Definisi Operasional \\ Pengetahuan Akuntansi $\left(\mathbf{X}_{1}\right)$}

Pengetahuan akuntansi merupakan penghasil informasi yang dalam hal ini menggambarkan kondisi suatu entitas ekonomi dan informasi tersebut digunakan sebagai dasar untuk pengambilan keputusan ekonomi yang prosesnya dilakukan oleh beberapa tahap yaitu identifikasi, pencatatan dan komunikasi. Informasi mengenai keuangan sangat dibutuhkan khususnya oleh pihak manajemen untuk membantu membuat keputusan suatu organisasi. Indikator yang digunakan ialah pengetahuan deklaratiif dan pengetahuan procedural. 


\section{Komitmen Organisasi $\left(\mathbf{X}_{2}\right)$}

Komitmen organisasi merupakan sikap atau loyalitas karyawan kepada organisasi dan ditandai dengan partisipasi pada organisasi sebagai titik fokus dan berlanjut sampai organisasi mencapai kesuksesan. Variabel komitmen organisasi diukur dengan beberapa pertanyaan. Pertanyaan tersebut diadopsi dari instrumen yang dikembangkan oleh Meyer, Natalie, dan Catherine (1993).

\section{Karakteristik Wirausaha $\left(\mathbf{X}_{3}\right)$}

Karakteristik wirausaha merupakan keseluruhan cara seorang untuk berinteraksi dan melihat peluang usaha serta menerjemahkannya menjadi usaha nyata yang memiliki nilai tambah serta memiliki karakteristik tingkat pengendalian internal, tingkat energi tinggi, kebutuhan tinggi akan berprestasi, tidak bekerja lebih giat karena adanya imbalan, toleransi terhadap ambiguitas, kepercayaan diri, dan berorientasi pada aksi. Variabel komitmen organisasi diukur dengan beberapa pertanyaan. Pertanyaan tersebut diadopsi dari instrumen yang dikembangkan oleh Steers dan Braunstein (1976).

\section{Ketidakpastian Lingkungan $\left(\mathbf{X}_{4}\right)$}

Ketidakpastian lingkungan merupakan ketidakmampuan lingkungan seseorang untuk memprediksi keadaan dimasa yang akan datang secara tepat dan akurat dari seluruh faktor yang secara langsung dapat memengaruhi perilaku seseorang dalam mengambil keputusan. Variabel komitmen organisasi diukur dengan beberapa pertanyaan. Pertanyaan tersebut diadopsi dari instrumen yang dikembangkan oleh Duncan (1972) dalam Yanita (2013).

\section{Kinerja Manajerial (Y)}

Kinerja manajerial merupakan ukuran seberapa efektif dan efisien manajer telah bekerja untuk mencapai tujuan organisasi. Variabel ini diukur dengan beberapa pertanyaan yang dikembangkan oleh Mahoney (1965).

\section{ANALISIS DAN PEMBAHASAN}

\section{Hasil Penelitian}

Penelitian ini menggunakan data primer yang diperoleh melalui kuesioner yang disebar kepada owner atau manajer coffee shop yang ada di Bandar Lampung dengan kriteria yang sudah disebutkan pada metode penelitian. Kuesioner yang disebar sebanyak 32 kuesioner dan kembali sebanyak 32 dengan tingkat pengembalian 100\%. Penelitian ini menggunakan regresi linear berganda untuk memeriksa kekuatan hubungan antar variabel independen dan variabel dependen. Variabel-variabel yang diteliti yaitu variabel dependen kinerja manajerial (Y) dan variabel independen yaitu pengetahuan akuntansi (X1), komitmen organisasi (X2), karakteristik wirausaha (X3), dan ketidakpastian lingkungan (X4). Dengan bantuan alat hitung SPSS versi 25 didapatkan data sebagai berikut:

\section{Uji Validitas}

Berdasarkan hasil perhitungan SPSS menunjukkan bahwa semua variabel yaitu dependen kinerja manajerial dan variabel independen yaitu pengetahuan akuntansi, komitmen organisasi, karakteristik wirausaha, dan ketidakpastian lingkungan valid. Nilai Rhitung menunjukkan hasil >0,350, sehingga dapat diproses untuk langkah berikutnya.

\section{Uji Reabilitas}

Hasil pengujian reliabilitas menunjukkan hasil dengan nilai koefisien alpha dari variabel-variabel yang diuji memiliki hasil dengan nilai cronbach alpha lebih besar dari 0,6. Dengan hasil tabel di atas dapat disimpulkan bahwa alat ukur yang digunakan dalam penelitian ini sudah reliabel. 


\section{Uji Normalitas}

Dapat disimpulkan berdasarkan grafik P-P Plot bahwa dalam penelitian ini, menunjukkan variabel yang diuji berdistribusi normalkarena garis titik-titik mengikuti garis diagonal. Hal ini juga menunjukkan bahwa penyebaran kuesioner penelitian ini telah terdistribusi normal dan mewakili beberapa pihak (subpopulasi). Dengan demikian, residual dalam penelitian ini telah memenuhi asumsi normalitas.

\section{Uji Heteroskedastisitas}

Berdasarkan pengolahan data menggunakan SPSS diketahui bahwa pola pada penyebaran data berupa titik-titik pada scatterplot tidak membentuk suatu pola atur alur tertentu, sehinga dapat disimpulkan bahwa tidak terjadi heteroskedastisitas. Dengan demikian uji klasik heteroskedastisitas dalam model ini terpenuhi. Uji ini dilakukan untuk mengetahui adanya penyimpangan dari syarat-syarat asumsi klasik pada regresi linear berganda yang dalam hal ini dalam model regresi harus dipenuhi syarat tidak adanya heteroskedastisitas.

\section{Multikolinearitas}

Hasil uji multikoliniearitas adalah ketiga variabel memiliki nilai tolerence di atas 0,1 dan tidak memiliki nilai VIF di atas 10. Jadi dapat diketahui bahwa dalam penelitian ini tidak terjadi korelasi antara variabel bebas atau tidak multikolinearitas.

\section{Hasil Analisis Linear Berganda}

Tabel 1. Hasil Analisis Linear Berganda

\begin{tabular}{lcc}
\hline \multicolumn{1}{c}{ Variabel } & \multicolumn{2}{c}{ Unstandardized Coefficients } \\
& B & Std. Error \\
\hline (Constant) & 28,002 & 7,383 \\
Pengetahuan Akuntansi & 1,140 & 0,371 \\
Komitmen Organisasi & 2,283 & 0,372 \\
Karakteristik Wirausaha & 1,235 & 0,346 \\
Ketidakpastian Lingkungan & $-1,135$ & 0,274 \\
\hline
\end{tabular}

Sumber: Data diolah dengan SPSS 25.

Tabel 1 menunjukkan bahwa nilai koefisien beta pengetahuan akuntansi (X1) sebesar 1,140, komitmen organisasi (X2) sebesar 2,283, karakteristik wirausaha (X3) sebesar 1,235, dan ketidakpastian lingkungan (X4) sebesar -1,135. Berdasarkan nilai tersebut maka persamaan regresinya adalah sebagai berikut:

$$
\mathrm{Y}=\mathbf{a}+\beta 1 \mathrm{X} 1+\beta 2 \mathrm{X} 2+\beta 3 \mathrm{X3}+\beta 3 \mathrm{X} 4+\varepsilon
$$

Dari persamaan rumus regresi linear berganda diperoleh:

$$
Y=28,002+1,140 \times 1+2,283 X 2+1,235 X 3-1,135 \times 4
$$

\section{Uji Signifikansi Parsial (Uji-t)}

Pengujian hipotesis dengan menggunakan uji t memasukkan nilai hasil perhitungan regresi linear berganda ke dalam uji t. Pengujian dengan uji t dapat dilakukan dengan membandingkan antara ttabel pada penelitian ini dengan $\mathrm{df}=\mathrm{n}-\mathrm{k}-1(32-5-1=26)$ dengan tingkat signifikasi pada $\mathrm{a}=0,05$ dan nilai Ttabel $=$ 1,694 . 
Tabel 2. Hasil Uji Hipotesis (Uji-t)

\begin{tabular}{|c|c|c|c|}
\hline Hipotesis & P-value & $\begin{array}{c}\text { Nilai Koefisien } \\
\text { Regresi }\end{array}$ & Hasil \\
\hline $\begin{array}{l}\text { H1: Pengetahuan Akuntansi berpengaruh positif } \\
\text { terhadap kinerja manajerial pada coffee shop di } \\
\text { Bandar Lampung. }\end{array}$ & 0,001 & 1,716 & $\mathrm{H}_{1}$ didukung \\
\hline $\begin{array}{l}\mathbf{H}_{2} \text { : Komitmen organisasi berpengaruh positif } \\
\text { terhadap kinerja manajerial pada coffee shop di } \\
\text { Bandar Lampung }\end{array}$ & 0,072 & 2,655 & $\mathrm{H}_{2}$ tidak didukung \\
\hline $\begin{array}{l}\text { H3: Karakteristik Wirausaha Berpengaruh Positif } \\
\text { Terhadap Kinerja Manajerial pada coffee shop di } \\
\text { Bandar Lampung. }\end{array}$ & 0,006 & 1,890 & $\mathrm{H}_{3}$ didukung \\
\hline $\begin{array}{l}\text { H4: Ketidakpastian lingkungan berpengaruh negatif } \\
\text { terhadap kinerja manajerial pada coffee shop di Bandar } \\
\text { Lampung }\end{array}$ & 0,005 & $-1,792$ & $\mathrm{H}_{4}$ didukung \\
\hline
\end{tabular}

Sumber: data yang diolah SPSS 25

\section{Uji Statistik F}

Tabel 3. Hasil Uji F

\begin{tabular}{lccccc}
\hline \multicolumn{1}{c}{ Model } & Sum of Squares & df & Mean square & F & Sig. \\
\hline Regression & 820,126 & 4 & 205,532 & 21,632 &, $000^{\mathrm{b}}$ \\
Residual & 339,749 & 27 & 12,583 & & \\
Total & 1159,875 & 31 & & & \\
\hline
\end{tabular}

Sumber: Data yang diolah SPSS 25

Berdasarkan hasil Tabel 4. 17 dapat diketahui bahwa pengujian variabel bebas secara bersama-sama terhadap variabel terikatnya dilakukan dengan menggunakan uji f. Hasil perhitungan statistik diperoleh $\mathrm{F}$ hitung sebesar 25,520 dan nilai signifikansinya sebesar 0,000 $<0,05$. Dengan nilai signifikansi di bawah 0,05 menunjukkan bahwa pengetahuan akuntansi, komitmen organisasi, karakteristik wirausaha, dan ketidakpastian lingkungan bersama-sama mempunyai kesesuaian pengaruh yang signifikan terhadap kinerja manajerial.

\section{PEMBAHASAN}

\section{Pengaruh Pengetahuan Akuntansi Terhadap Kinerja Manajerial}

Pengetahuan akuntansi dapat didefinisikan sebagai seperangkat ilmu tentang informasi yang menghasilkan laporan keuangan kepada pihak yang berkepentingan mengenai aktivitas ekonomi dan kondisi perusahaan Sitorus (2017). Baridwan (2004)menjelaskan bahwa salah satu tujuan penyusunan laporan keuangan adalah untuk menunjukkan sumber-sumber ekonomi dari suatu perusahaan, klaim atas sumbersumber tersebut, dan pengaruh dari transaksitransaksi, kejadian-kejadian, dan keadaan-keadaan yang memengaruhi sumber-sumber dan klaim atas sumber-sumber tersebut. Indikator pengetahuan akuntansi menggunakan dua dimensi pengukuran yang biasanya digunakan dalam kajian audit Bonner yaitu pengetahuan deklaratif dan pengetahuan prosedural.

Hasil pengujian hipotesis nilai pengetahuan akuntansi menunujukkan arah positif dengan nilai koefisin 1,716 dan nilai signifikan $0,001<0,05$ sehingga dapat disimpulkan bahwa variabel pengetahuan akuntansi berpengaruh positif terhadap kinerja manajerial dan $\mathrm{H} 1$ diterima. Hal ini berarti hubungan pengetahuan akuntansi terhadap kinerja manajerial berpengaruh positif dikarenakan apabila manajer suatu perusahaan memiliki pemahaman pengetahun akuntasi dengan baik maka kinerja manajerial perusahaan tersebut akan tinggi pula. Hasil penelitian tersebut sejalan dengan penelitian Resa (2013)yang meneliti tentang pengaruh pengetahuan akuntansi terhadap kinerja manajerial pada usaha kecil menengah di Kabupaten Sleman Yogyakarta. Hasil penelitian tersebut menyatakan pengetahuan akuntansi berpengaruh 
positif terhadap kinerja manajerial pada usaha kecil menengah. Penelitian ini juga sejalan dengan penelitian yang dilakukan oleh Siregar (2009)tentang pengaruh pengetahuan akuntansi terhadap kinerja manajerial pada perusahaan jasa di kota Medan. Hasil tersebut menunjukkan pengetahuan akuntansi berpengaruh positif terhadap kinerja manajerial pada perusahaan jasa di kota Medan.

\section{Pengaruh Komitmen Organisasi Terhadap Kinerja Manajerial}

Komitmen organisasi salah satu konsep tingkah laku pada pekerjaan yang berhubungan dengan ada tidaknya keterkaitan perseorangan pada organisasi. Hasil pengujian hipotesis nilai komitmen organisasi menujukkan arah positif dengan nilai koefisien beta sebesar 2,655 dan nilai signifikan 0,072>0,05 sehingga dapat disimpulkan bahwa variabel komitmen organisasi berpengaruh negatif secara signifikan dan $\mathrm{H} 2$ ditolak. sehingga dapat disimpulkan bahwa dalam penelitian ini unit manajerial perusahaan memiliki sikap loyal yang rendah dan keinginan berpindah yang tinggi. Ketika komitmen organisasi dalam suatu perusahaan berpengaruh negatif terhadap kinerja manajerial, maka dapat disimpulkan bahwa gaya dan kualitas kepemimpinan yang diterapkan tidaklah sesuai dengan harapan para bawahan sehingga berdampak pada turunnya kinerja manajerial.

Lalu hasil penelitian komitmen organisasi mendukung hasil penelitian yang dilakukan oleh Wartini (2015)melakukan penelitian dan menunjukkan bahwa komitmen organisasi berpengaruh positif dan signifikan pada kinerja manajerial. Berbeda dengan penelitian yang dilakukan Wijayanti, (2012)menyatakan bahwa komitmen organisasi berpengaruh negatif terhadap kinerja manajerial.

\section{Pengaruh Karakteristik Wirausaha Terhadap Kinerja Manajerial}

Karakteristik wirausaha juga sejalan dengan penelitian sebelumnya yaitu Peneliti Siregar, (2009) meneliti tentang pengaruh kepribadian wirausaha terhadap kinerja manajerial pada perusahaan jasa di kota medan. Hasil penelitian menunjukkan bahwa kepribadian wirausaha berpengaruh positif terhadap kinerja manajerial dalam suatu perusahaan. Sama dengan Putra (2018)menyatakan bahwa kepribadian kewirausahaan berpengaruh signifikan terhadap kinerja manajerial.

\section{Pengaruh Ketidakpastian Lingkungan Terhadap Kinerja Manajerial}

Berdasarkan penelitian yang telah dilakukan, maka penelitian ini menunjukkan bahwa nilai Fhitung sebesar 25,520 dengan nilai signifikan $0,000<0,05$ maka hal ini menyatakan secara simultan variabel yang diteliti berpengaruh signifikan terhadap kinerja manajerial pada coffee shop di Bandar Lampung. Besarnya peran pengetahuan akuntansi (X1), komitmen organisasi (X2), karakteristik wirausaha (X3), dan ketidakpastian lingkungan (X4) dalam kinerja manajerial masing-masing sebesar 1,018, 2,431, 1,682, dan $-1,815$. Variabel yang berpengaruh dominan terhadap kinerja manajerial adalah komitmen organisasi. Hal ini dapat dilihat berdasakan koefisien regresi yang memiliki nilai tertinggi yaitu 2,431 dengan signifikan sebesar 0,005 .

Variabel ketidakpastian lingkungan yang juga sejalan dengan peneliti sebelumnya yaitu hasil penelitianHerawati dkk(2015) menghasilkan bahwa ketidakpastian lingkungan tidak berpengaruh terhadap kinerja manajerial. Hasil ini sama dengan penelitian yang dilakukan oleh Fiolita dkk (2015)menghasilkan bahwa ketidakpastian lingkungan berhubungan negatif terhadap kinerja manajerial.

\section{E. SIMPULAN DAN SARAN}

\section{Simpulan}

Berdasarkan hasil-hasil pengujian dan analisis yang telah dilakukan maka simpulan yang dapat diambil sebagai berikut:

1) Variabel $X_{1}$ pengetahuan akuntansi berpengaruh positif secara signifikan terhadap kinerja manajerial dalam studi kasus coffee shop di Bandar Lampung. 
2) Variabel $X_{2}$ komitmen organisasi berpengaruh positif secara signifikan terhadap kinerja manajerial dalam studi kasus coffee shop di Bandar Lampung.

3) Variabel $X_{3}$ karakteristik wirausaha berpengaruh positif secara signifikan terhadap kinerja manajerial dalam studi kasus coffee shop di Bandar Lampung.

4) Variabel $X_{4}$ ketidakpastian lingkungan berpengaruh negatif secara signifikan terhadap kinerja manajerial dalam studi kasus coffee shop di Bandar Lampung.

Saran

Berdasarkan simpulan di atas, maka terdapat beberapa saran untuk peneliti selanjutnya yang membahas dengan judul yang sama. Adapun saran tersebut adalah sebagai berikut:

1) Peneliti selanjutnya yang tertarik untuk meneliti judul yang sama, agar dapat memperluas sampel dan menambahkan variabel lain seperti budaya organisasi, dan keterlibatan kerja, strategi, kompetensi atau menjadikan variabel tersebut sebagai variabel pemoderasi maupun variabel intervening dalam penelitian yang akan dilakukan. Untuk meningkatkan kinerja manajerial maka perusahaan memanfaatkan teknologi informasi yang ada, mempertahankan keefektifan sistem akuntansi manajemen dan mengantisipasi ketidakpastian lingkungan yang ada.

2) Penelitian selanjutnya diharapkan dapat memperluas penelitian dengan menambahkan sampel tidak hanya berfokus pada daerah Bandar Lampung saja. Sehingga dapat diperoleh hasil penelitian dengan tingkat generalisasi yang lebih tinggi dan lebih baik.

\section{REFERENSI}

Baridwan, Z. (2004). Intermediate Accounting. Edisi kedelapan. Yogyakarta: BPFE.

Bonner, W. (1994). The Effect of Instruction and Experience on The Acqyition of Auditing Knowledge. The Accounting Review, 69(1), 157-178.

Desmiyawati. (2010). Pengaruh Desentralisasi, Ketidakpastian Lingkungan dan Sistem Akuntansi Manajemen Terhadap Kinerja Manajerial. PekBis Jurnal, 2(3), 346-354.

Fiolita, M. , Desmiyawati, \& Natariasari, R. (2015). Pengaruh Intensitas Kompetisi dan Ketidakpastian Lingkungan Terhadap Kinerja Organisasi dengan Karakteristik Informasi Sistem Akuntansi Manajemen Sebagai Variabel Intervening (Studi Empiris Pada Perusahaan Asuransi di Kota Pekanbaru). Jurnal Online Manajemen, 2(1).

Herawati, T. , Fatma, Y. , \& Sari, L. (2015). Pengaruh Ketidakpastian Lingkungan dan Karakteristik Informasi Sistem Akuntansi Manajemen Terhadap Kinerja Manajerial. Study Accounting Research, 12(1), 29-38. Hoetomo. (2005). Kamus Lengkap Bahasa Indonesia. Mitra Pelajar.

Kasmir. (2016). Manajemen Sumber Daya Manusia (Teori dan Praktik)-Cetakan Kesatu. Raja Grafindo Persada.

Kurniawan, A. (2015). Pengaruh Komitmen Organisasi Terhadap Organizational Citizenship Behavior (OCB) PT X Bandung. Jurnal Manajemen Maranatha, 15(1), 95-118.

Mangkunegara, A. (2017). Evaluasi Kinerja. Bandung: Refika Aditama.

Mardiana, Shabrina, Q. , Sakinah, \& Sopiana, M. (2020). Pengaruh Pengetahuan Akuntansi Dan Kepribadian Wirausaha Terhadap Kinerja Manajerial Pada Bni Syariah Kcp Cengkareng. Prosiding Webinar.

Masram, \& Mu'a. (2017). Manajemen Sumber Daya Manusia. Zifatama Publisher.

Putra, J. W. (2018). Pengaruh Penggunaan Sistem Akuntansi Manajemen Dan Kepribadian Kewirausahaan Terhadap Kinerja Manajerial Di Koperasi Tani Sejahtera Trenggalek. Jurnal Universitas Nusantara PGRI Kediri, Vol. 8(No. 3), 1-19.

Rahardjo, P. (2012). Panduan Budidaya dan Pengolahan Kopi Arabika dan Robusta. Jakarta:Penebar Swadaya.

Rahman, A. (2013). Pengaruh Perilaku Individu Terhadap Kinerja Pegawai Pada Kantor Wilayah Departemen Agama Provinsi Riau. Jurnal Ilmiah Cano Ekonomos, 2(1), 1-19.

Rahmawati, S. dan, \& Nuraini, A. L. R. (2012). CBAM-FE Pengaruh Partisipasi Anggaran Dan Informasi Akuntansi Terhadap Kinerja Manajerial : Komitmen. 1(1), 99-120.

Resa, K. F. (2013). Pengaruh Pengetahuan Akuntansi, Kepribadian Wirausaha Dan Ketidakpastian Lingkungan Terhadap Kinerja Manajer Pada Usaha Kecil Menengah (Ukm) Di Kabupaten Sleman ogyakarta. Jurnal UPN Yogyakarta. 
Ridwan, M. , \& Hamelinda, F. (2017). Pengaruh Gaya Kepemimpinan, Motivasi Kerja, Dan Komitmen Organisasi Terhadap Kinerja Manajerial (Survey Pada Kantor Cabang Pembantu Bank Di Kota Sungai Penuh). Jurnal Manajemen Terapan Dan Keuangan, 6(3), 169-181. https://online-journal. unja. ac. id/mankeu/article/view/4251/5971

Ridwan, M. , \& Sandi, H. E. (2019). Pengaruh Interaksi Antara Total Quality Management Dengan Sistem Penghargaan, Komitmen Organisasi Dan Sistem Pengukuran Kinerja Terhadap Kinerja Manajerial (Studi Empiris Pada Perusahaan Otomotif Dan Komponen Di Kota Jambi). Jurnal Manajemen Terapan Dan Keuangan, 8(1), 13-28. https://doi. org/10. 22437/jmk. v8i1. 6931

Sengkeh, D. , Rumawas, W. , \& Tumbel, T. (2017). Pengaruh Komitmen Organisasional Terhadap Prestasi Kerja Karyawan Pada PT Permodalan Nasional Madani (Persero) Cabang Manado. None, 5(003). https://doi. org/10. 35797/jab. 5. 003. 2017. 16566.

Siregar, A. (2009). Engaruh Pengetahuan Akuntansi Dan Kepribadian Wirausaha Terhadap Kinerja Manajerial Pada Perusahaan Jasa Di Kota Medan. Skripsi. Universitas Sumatra Utara.

Siregar, S. (2013). Metode Penelitian Kuantitatif: Dilengkapi Dengan Perbandingan Perhitungan Manual dan SPSS. Jakarta:Kencana.

Sitorus, S. D. H. (2017). Pengaruh Latar Belakang Pendidikan dan Pengetahuan Tentang Akuntansi Terhadap Penggunaan Sistem Informasi Akuntansi Pada Pedagang di Wilayah Kelurahan Helvetia Tengah Medan. At-Tawassuth, 2(2), 413-436.

Subkhi, A dan Jauhan, M. (2013). Pengantar Teori dan Perilaku Organisasi. Surabaya:Prestasi Pustaka.

Sutrisno, E. (2014). Manajemen Sumber Daya Manusia. Edisi Pertama. Jakarta: Kencana Prenada Media Group.

Suwardjono. (2002). Pengantar Akuntansi. Yogyakarta: BPFE.

Wartini, S. (2015). Strategi Manajemen Konflik Sebagai Upaya Meningkatkan Kinerja Teamwork Tenaga Kependidikan. Jurnal Manajemen Dan Organisasi, 6, No. 1.

Wijayanti, T. (2012). Pengaruh Budaya dan Komitmen Organisasi Antara Partisipasi Penganggaran dan Kinerja Manajerial Perushaan AMDK di Pasuruan. Jurnal Manajemen UMM, 2(1).

Winardi. (2003). Entrepreneur dan Entrepreneurship. Jakarta: Kencana. 